\title{
Investigation of the DI Diesel Engine Performance using Ethanol-Diesel Fuel Blends
}

\author{
Malee Suntikunaporn ${ }^{1}$, Snunkhaem Echaroj ${ }^{1}$ and Channarong Asavatesanupap ${ }^{2}$ \\ ${ }^{1}$ Department of Chemical Engineering, Faculty of Engineering, Thammasat University, Pathumthani, Thailand 12120 \\ ${ }^{2}$ Department of Mechanical Engineering, Faculty of Engineering, Thammasat University, Pathumthani, Thailand 12120
}

\begin{abstract}
Ethanol-diesel blend is a promising candidate as a fuel for direct injection (DI) diesel engine. In this research, solubility of different compositions of ethanol-diesel blends from 2 to $15 \%$ (v/v) ethanol were tested for 20 days. Significant increases in solubility of the blends were observed after addition of $1 \%(\mathrm{v} / \mathrm{v}) n$-butanol. The Kubota's RT140 diesel engine was operated using E7B1D92 blend at several engine speeds (1,000 to 1,600 rpm). The obtained results demonstrated that, when using E7B1D92 blend at an engine speed of 1,500 rpm, the engine power and torque of the RT140 engine were increased from 8.6 PS to $10.1 \mathrm{PS}$ and $4.1 \mathrm{~kg}_{\mathrm{f}}-\mathrm{m}$ to $5.1 \mathrm{~kg}_{\mathrm{f}}-\mathrm{m}$ compared to pure diesel fuel. However, specific consumption fuel increased when E7B1D92 blend was used during the engine test. Additionally, analysis of exhaust gas revealed a decrease in smoke density when E7B1D92 was used instead of pure diesel.
\end{abstract}

\section{Introduction}

A clear deficit in the supply of fossil fuel diesel have driven millions of car-users to convert to vehicle powered by alternative sources of fuel such as biodiesel, gasohol (ethanol-gasohol blend) and even electricity. According to the World Oil Outlook, demand of diesel fuel is projected to increase from 26 million barrels per day $(\mathrm{mb} / \mathrm{d})$ to $36 \mathrm{mb} / \mathrm{d}$ by 2035 [1]. As a result, in order to reduce our dependency on fossil fuel, researches are now considering the possibility of mixing renewable fuel with fossil-derived diesel for diesel injection engine. In Thailand the Ministry of Energy planned to replace 44\% of crude oil consumption with biofuels such as ethanol and biodiesel by 2021 [2]. Fortunately, ethanol is a renewable material that can be produced through fermentation of sugar cane [3], fruit peels and various lignocellulose materials [4]-[6].

Ethanol has a high octane number which makes it compatible for spark ignition (SI) engine. However, ethanol has a cetane number of approximately 5 which is very low compared to diesel oil with cetane number of 50 . Additionally, the molecular weight of ethanol differs greatly from diesel molecule [7]. For these reasons, ethanol cannot be used directly for compression ignition diesel engine. Ethanol has to be blend with diesel to make a solution mixture which is usually referred to as diesohol.

The solubility of ethanol in diesel was observed in many researches in term of how long the blended solution remains in a homogenous solution after mixing. The ethanol-diesel blend consisting of $10 \%(\mathrm{v} / \mathrm{v})$ was found to remain in a homogenous phase for 72 hours, whereas the blends with 20 and $30 \%(\mathrm{v} / \mathrm{v})$ ethanol separated into two phases 24 hours and 5 minutes after agitation. Addition of $5 \%(\mathrm{v} / \mathrm{v}) n$-butanol to the 20 and $30 \%(\mathrm{v} / \mathrm{v})$ ethanol solution was found to lengthen duration at which the solutions remain in one phase to 14 days and 11 days [8]. Additionally, $n$-butanol was found to successfully enhanced solubility of the water-containing ethanolbiodiesel-diesel blends [9]. An improvement in solubility of the blend was due to the polarity of $n$-butanol's hydroxyl which facilitates ethanol's solubility in diesel. Another kind of additive that had been employed frequently was Sorbitan methyl- ester [10], [11]. A research reported that solvents that are capable of improving the solubility of ethanol-diesel blends have to contain a hydrogen donor group, a hydrogen acceptor group and a nonpolar group. The hydrogen donor groups (eg. $-\mathrm{OH},-\mathrm{SH},=\mathrm{NH}$ and $-\mathrm{NH}_{2}$ ) and hydrogen acceptor groups (eg. $=\mathrm{N}-,=\mathrm{O},=\mathrm{S},-\mathrm{NH}-$ ) have high affinity with polar substance present in the blend. Additionally, nonpolar group interacts strongly with hydrocarbons in the blend through the vander-waal molecular interaction forces [12], [13].

Utilization of ethanol-diesel blend as a fuel for diesel engine has been investigated in many researches. Shadidi et al reported an increased in engine power of at least $3.17 \%$ after $99.6 \%$ ethanol was blended with pure diesel and tested with a diesel engine containing 6 cylinders. However it was also found that the specific consumption increased by approximately 7.3 to $15.8 \%$ [14]. Another 
experiment conducted using 6 cylinder diesel engine revealed that the specific fuel consumption of ethanoldiesel blend was higher than that of pure diesel [15], [16]. Apart from diesel fuel that is derived from refining fossil fuel, bio-oil from pyrolysis of wood has also been shown to improve during combustion in a dual injection diesel engine when mixed with ethanol. This is because bio-oil from pyrolysis of biomass alone is constrained by its poor physical properties, such as high acidity and low energy density.

Moreover, bio-oil from pyrolysis of biomass usually contains free-radical which promote polymerization during combustion at high temperature or even during storage at ambient temperature. Addition of ethanol to bio-oil has been found to help reduce polymerization activities [17]. There are more researches on the subject of testing the performance of ethanol-diesel blend using either 6 cylinders diesel engine or a modified diesel engine [18]-[21]. Unfortunately, so far very few researches have investigated how ethanol-diesel blends with and without addition of co-solvent perform on a 1 cylinder diesel engine.

In the present work, we report the solubility testing of blends or diesohol with different ethanol-to-diesel ratio from $2 \%$ to $15 \%(\mathrm{v} / \mathrm{v})$ ethanol; E2B1D93, E4B1D95, E7B1D92, E10B1D89, and E15B1D84. Additionally, the effect of adding $1 \%(\mathrm{v} / \mathrm{v}) n$-butanol on the solubility of the solution was also investigated. Performance of the 1cylinder Kubota's RT140 diesel engine was evaluated according to the specific fuel consumption, engine power output, torque and exhaust density at different engine rotational speeds.

\section{Experimental setup}

\subsection{Blending and solubility testing}

Ethanol-diesel blends were prepared by mixing diesel and ethanol for 10 minutes at a rotation speed of 2000 $\mathrm{rpm}$ using an agitator. For some experiment $1 \% \mathrm{v} / \mathrm{v} n$ butanol was added as co-solvent to help increase the solubility and stability of the blends. The additive was added immediately after the ethanol diesel solution was prepared and the agitator was used to blend the solution again for another 15 minutes at $2000 \mathrm{rpm}$. After the solution appeared to be homogenous each blend was transformed to a flask and place at ambient temperature for 20 days in order to examine the solubility of each blend. A picture of each blend was capture 30 minutes, 10 days and 20 days after the solutions' preparation.

\subsection{Engine performance testing}

Engine performance was examined using a single cylinder, four stroke Kubota RT140 DI diesel engine with specifications as outlined in Table 1. The engine was coupled by a shaft to an eddy current dynamometer executed by a Tokyokoki-Schenck controller device. The engine is cooled by water circulating from the cooling tower located outside the engine testing laboratory. An automated solenoid controlled type-flow meter from
Tokyo Kokukeiki Company was used to measure the fuel consumption. A fuel tank was used to store $6 \mathrm{~L}$ of fuel for the engine. The exhaust gas was captured by a nozzle and was delivered to be analyzed by Sokken GSM-3 smoke meter which utilize filter paper and light detecting technologies. The crank angle or fuel-delivery angle inside the engine was adjusted to $19.2^{\circ}$ by combining 0.2 and $1^{\circ}$ metal sheets. The controller monitor was used to observe the rate consumption of fuel, exhaust gas temperature (T1), oil temperature (T2) and smoke density of the exhaust gas. The controller was also used to adjust the engine speed and torque. A detail diagram of the system is shown in Figure 1.

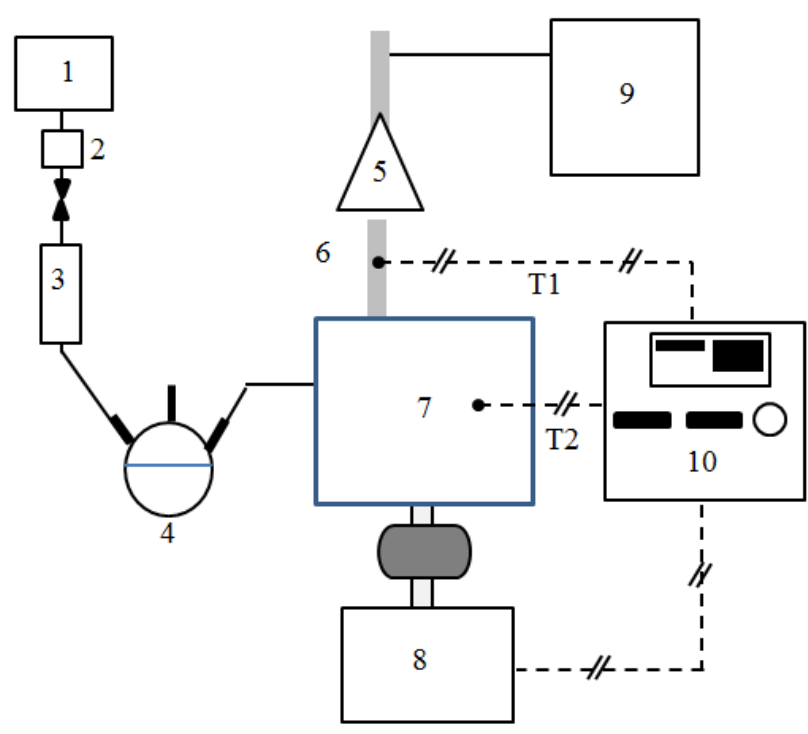

Figure 1 Experimental setup diagram of engine test facilities; 1. Fuel feed tank, 2. Filter, 3. Flow controller, 4. Feed modification, 5. Exhaust gas nozzle, 6. Exhaust gas, 7. Diesel engine, 8. Eddy dynamometer, 9. Smoke meter, and 10. Dynamometer controller device.

Table 1 RT140 DI Engine specifications

\begin{tabular}{|l|l|}
\hline Parameter & Basic specification \\
\hline Model & Kubota RT140 (Thailand) \\
\hline Number of cylinder & 1 \\
\hline Type & $\begin{array}{l}\text { Direct injection diesel engine } \\
4 \text { stroke }\end{array}$ \\
\hline Bore x stroke & $97 \times 96 \mathrm{~mm}$ \\
\hline Displacement & $709 \mathrm{cc}$ \\
\hline Compression ratio & $18: 1$ \\
\hline Maximum power & $14.0 \mathrm{HP} / 2400 \mathrm{rpm}$ \\
\hline Maximum torque & $5.0 \mathrm{~kg}-\mathrm{m} / 1600 \mathrm{rpm}$ \\
\hline Injector pressure & $200 \mathrm{~kg} / \mathrm{cm}^{2}$ \\
\hline
\end{tabular}


The performance was recorded from a dynamometer and reported in terms of engine power (calculated by Equation 1), specific fuel consumption (calculated by Equation 2), and smoke density of the exhausted gas.

Power $=\frac{\text { Torque } \times \text { Speed }}{716.2}(P S)$

Specific fuel consumption $=\frac{F_{f} \rho_{f}}{P o w e r}\left(\frac{g}{P S \cdot h}\right)$

Where $F_{f}$ is the flow rate of the either ethanol-diesel blend or pure diesel fuel that is consumed by the diesel engine and $\rho_{\mathrm{f}}$ is the bulk density of the blend and fuel. The unit for engine speed is $\mathrm{rpm}, \mathrm{kg}_{\mathrm{f}}-\mathrm{m}$ for engine toqure, g/PS-h for specific energy consumption, PS for engine power, and BSU for exhaust density.

\section{Results and discussion}

\subsection{Blending and solubility testing}

As shown in Figure 2, E15D85 blend separated into two phases after 30 minutes while the rest remained in a homogeneous solution. A two headed gray arrow was included in the figures beside the blend to highlight the separation of ethanol and diesel. A homogeneous solution appeared as a transparent clear yellowish color. It was found that E10D90 remained a homogeneous solution for roughly 30 minutes, but after 10 days it was observed to be separated into two phases. Ethanol content in E4D06 and E7D93 were observed to be completely miscible with diesel's hydrocarbon during the first 19 days. However, after 20 days E4D96 and E7D93 blends separated into two phases. E2D98 blend was still observed to remain in a homogeneous phase even after 20 days after agitation.

For the next part, an additive, $1 \%(\mathrm{v} / \mathrm{v}) n$-butanol, was added after ethanol and diesel was agitated. Addition of $n$-butanol was observed to increase the solubility of E10B1D94 from 30 minutes to 10 days. It was found, as shown in Figure 3, that even after addition of additive E15B1D94 still separated into two phases almost immediate after agitation. However, after 20 days the E10B1D89 blend was separated into two phases. The blends that remain homogenous for at least 20 days are E2B1D97, E4B1D95 and E7B1D92 blends. An increase in the percentage of $n$-butanol can help increase the solubility of $15(\mathrm{v} / \mathrm{v} \%)$ ethanol in diesel fuel. It can be concluded that that additional of $n$-butanol was successful in improving the solubility of ethanol in diesel.

\subsection{Engine performance testing}

The ethanol-diesel blend (E7B1D92) was prepared and some properties such as density, viscosity and heating value were analysed. The significant properties of the blend compared to pure diesel are summarized in Table 2. According to Table 2, addition of ethanol to diesel was found to decrease the density, viscosity and heating value of the fuel.
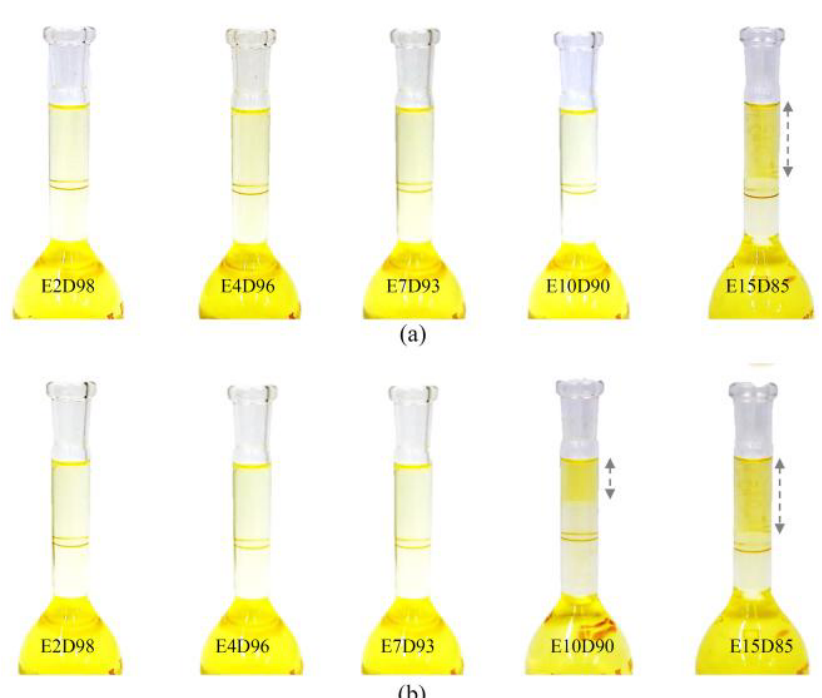

(b)
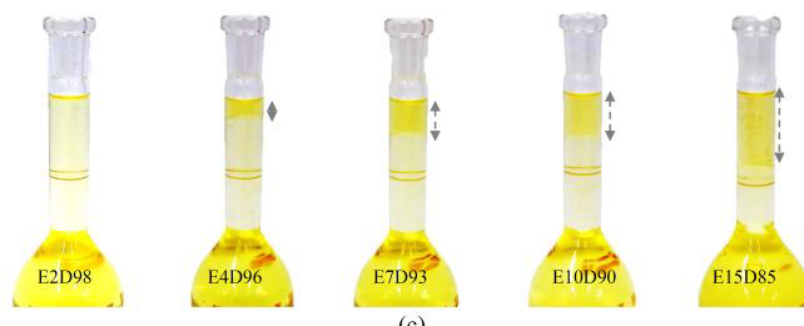

Figure 2 Solubility of different ethanol-diesel blends without $n$-butnaol 30 minutes a), 10 days b) and 20 days c) after agitation.

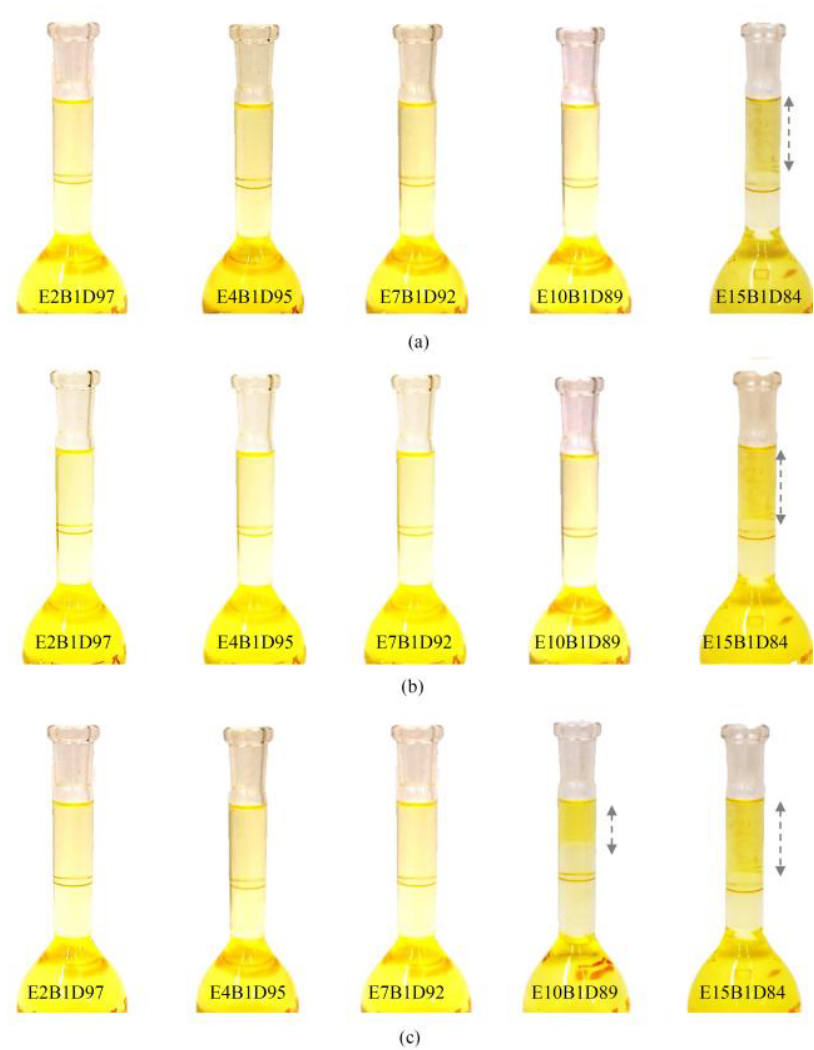

Figure 3 Solubility of different ethanol-diesel blends with $n$-butnaol 30 minutes a), 10 days b) and 20 days c) after agitation. 
Table 2 Properties of E7B1D92 blends

\begin{tabular}{|l|l|l|}
\hline Properties & Pure diesel & E7B1D92 \\
\hline Density $30^{\circ} \mathrm{C}$, & $837 \mathrm{~kg} / \mathrm{m}^{3}$ & $833 \mathrm{~kg} / \mathrm{m}^{3}$ \\
\hline Kinetic viscosity $40^{\circ} \mathrm{C}$ & $2.6 \mathrm{cSt}$ & $2.5 \mathrm{cSt}$ \\
\hline Lower heating value & $43.0 \mathrm{MJ} / \mathrm{Kg}$ & $41.7 \mathrm{MJ} / \mathrm{Kg}$ \\
\hline
\end{tabular}

The relationship between engine power and engine speed for E7B1D92 was illustrated in Figure 4. It can found that the maximum engine power was attained at the engine speed of $1500 \mathrm{rpm}$. An increase in ethanol content clearly resulted in an increase in engine power. It can be observed that the maximum engine power of E7B1D93 blend was 10.1 PS, while pure diesel gave only 8.6 PS. Engine power for both ethanol-diesel blended fuel and pure diesel decrease to approximately 7 PS after the engine speed is reduced from $1500 \mathrm{rpm}$ to $1000 \mathrm{rpm}$. Although the blended fuel has lower heating value compared to pure diesel, it gave significantly higher engine power. This is because the molecular formula for ethanol is $\mathrm{C}_{2} \mathrm{H}_{5} \mathrm{OH}$ which contain of an oxygen atom (approximately 35\% oxygen). During combustion, fuel reacts with oxygen to release the desirable amount of energy. The engine will undergo a complete combustion when the content of oxygen in the system is sufficient. In contrary, if there is not enough oxygen then incomplete combustion will occur causing the diesel engine to perform below its capability. Therefore, the presence of ethanol molecule increases the supply of oxygen in the chamber, which results in a complete combustion and higher engine power.

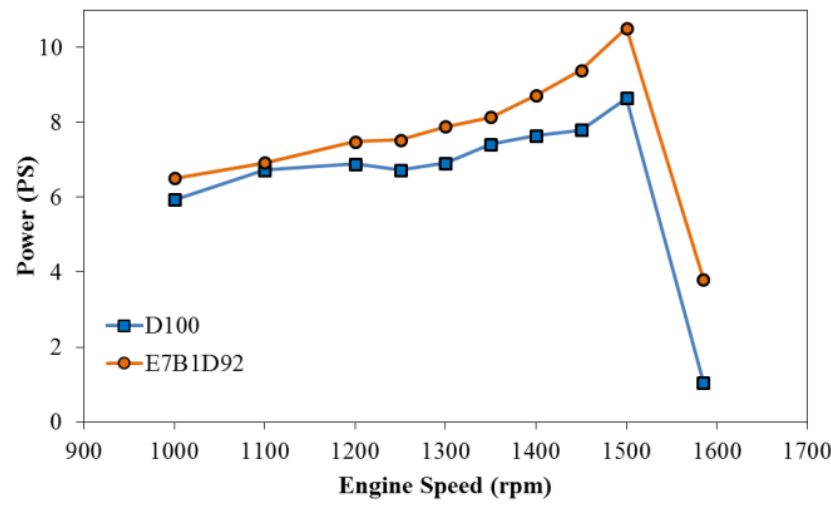

Figure 4. Relationship between engine power and engine speed of E7B1B92 blend and pure diesel

Variations of torque (kgf-m) with different engine speeds $(1000-1600 \mathrm{rpm})$ were shown in the graph below. As shown in Figure 5, engine torque of the ethanol-diesel blend fuel is higher than that of the pure diesel. The result shows that at engine speed of 1,500 rpm E7B1D92 blend produce a torque of $5.1 \mathrm{~kg}_{\mathrm{f}} \mathrm{m}$. For pure diesel the maximum torque produced at $1500 \mathrm{rpm}$ was only $4.1 \mathrm{~kg}_{\mathrm{f}}$ $\mathrm{m}$. The increase in engine torque is again attributed to an increase in oxygen content due to combustion of ethanol molecules. Torque from ethanol-diesel blended fuel decreased to approximately $4.8 \mathrm{~kg}_{\mathrm{f}}-\mathrm{m}$ and remained constant from $1000 \mathrm{rpm}$ to $1400 \mathrm{rpm}$. Similarly for pure diesel, torque remained constant at $4.2 \mathrm{~kg}_{\mathrm{f}}-\mathrm{m}$.

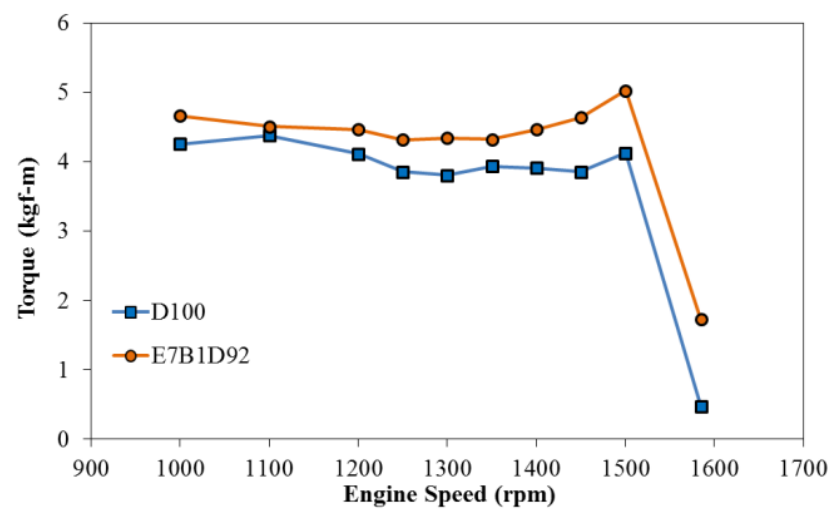

Figure 5. Relationship between torque and engine speed of E7B1B92 blends and pure diesel.

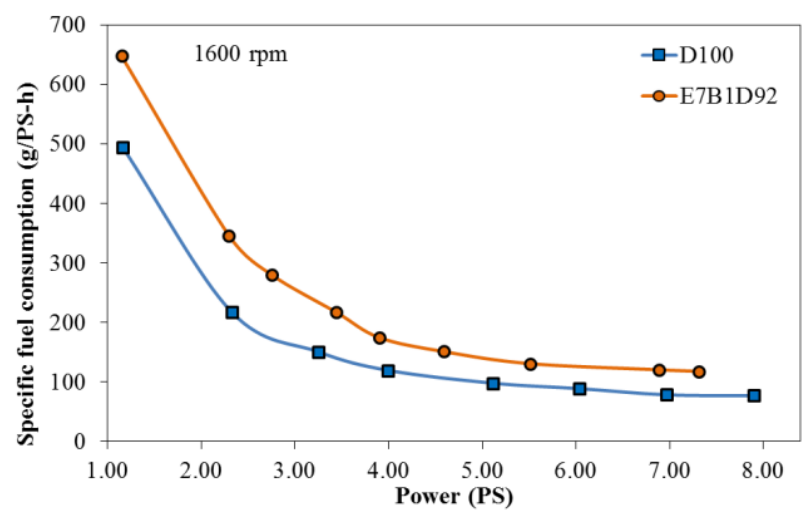

Figure 6. Relationship between specific fuel consumption and engine power of E7B1B92 blend and pure diesel for the engine speed of $1,600 \mathrm{rpm}$.

Variation of specific fuel consumption with engine speed is shown in Figure 6. The specific fuel consumption can be defined as the mass of fuel flow rate in $\mathrm{g} / \mathrm{h}$ at one engine power output in PS. It is an important specification used to investigate the performance of the diesel engine. As shown in Figure 6, an increase in specific fuel consumption was observed as the content of ethanol was increased. At an engine power output of 1.2 PS the specific fuel consumption for E7B1D92 blend was found to increase by $31.1 \%$ compared to pure diesel. At 5.1 PS engine power output the specific fuel consumption for E7B1D92 blend was found to increase by $33.5 \%$ compared to pure diesel. The increase in the specific fuel consumption required for combustion of bended fuel is reasonable due to the lower heating values of ethanoldiesel blend compared to that of pure diesel. Lower heating value is defined as the heat release out of a combustion system given that the initial and final state of the products and reactants are at the same temperature. As shown in Table 2, the lower heating value for $7 \mathrm{v} / \mathrm{v} \%$ ethanol-diesel blends was only $41.7 \mathrm{MJ} / \mathrm{Kg}$, while pure diesel gave a heating value of $43.0 \mathrm{MJ} / \mathrm{Kg}$. Other studies also found that the fuel with lower heating value operated at a significant higher specific fuel consumption than fuel with higher heating value such as pure diesel [3]-[6]. 


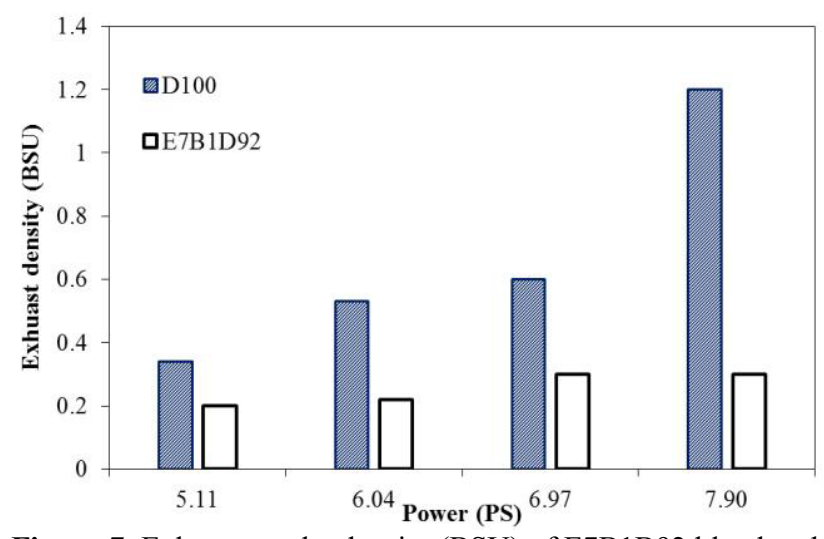

Figure 7. Exhaust smoke density (BSU) of E7B1B92 blend and pure diesel at four different loads for the engine speed of 1600 rpm.

Figure 7 shows that the soot or smoke produced by the ethanol-diesel blend is significantly lower than that produced from pure diesel. When the diesel engine is operated at 7.9 PS addition of ethanol caused the exhaust gas to reduce from 1.2 to as low as $0.3 \mathrm{BSU}$. When ethanol was added at the engine power of 5.1 PS, the exhausted density reduced from 0.38 to $0.2 \mathrm{BSU}$. This is also due to an increase in oxygen content during combustion of oxygen containing ethanol molecules which help improve the completeness of the combustion. Additionally it is demonstrated in Figure 7 that an increase in engine power from 5.11 PS to 7.9 PS results in an increase in the smoke density. For pure diesel the smoke density increases significantly from 0.38 to 1.2 BSU. However, for the ethanol-diesel blend the smoke density increases only slightly. Other researches investigating combustions of blends fuel using diesel engine yielded similar results. For instance, Chen et al. and Xingcai et al. revealed flame propagation and combustion duration by capturing in-cylinder photos during combustion of blends and pure diesel at different crank angles. The luminosity during combustion of pure diesel was observed to be significantly larger than that of the ethanol-diesel blend, which indicated higher formation of soot particulate in the chamber. Therefore, in their research it was also revealed that ethanol can help suppress soot formation [22]-[24].

\section{Conclusions}

In conclusion it was found that solubility of ethanoldiesel blends can be improved by addition of $1 \%(\mathrm{v} / \mathrm{v}) n$ butanol. However, it was observed when the composition of ethanol was equalled to or higher than $10 \%(\mathrm{v} / \mathrm{v})$ the blended solution separated into two layers after 20 days even after addition of $n$-butanol. Engine performance testing of the E7B1D92 blend revealed a significant increase in engine power and torque at 1,500 rpm compared to pure diesel fuel. However, specific fuel consumption also increase when E7B1D92 was tested and compared to pure diesel due to ethanol's significantly higher heating value than pure diesel fuel. Exhaust gas emitted during engine testing using E7B1D92 as a fuel was found to produce lower smoke density compared to that emitted from pure diesel fuel.

\section{Acknowledgement}

This work was supported by Faculty of Engineering, Thammasat University. Also, thanks to SIAM KUBOTA Corporation Co. Ltd for laboratory testing supports. One of us (S.E.) thanks Thammasat University for a scholarship.

\section{References}

1. L. Hermida, A.Z. Abdullah, A.R. Mohamed, Renew. Sustain. Ener. Rev. E 42, 1223-33 (2015)

2. Thailand Board of Investment. Bangkok Thailand Board of Investment (2013).

3. S. Kumara, P. Dheerana, S.P. Singhe, I.M. Mishrab, D.K. Adhikari, Renew. Ener. E 83, 850-8 (2015)

4. R.S. Orozco, Bioresources E 9, 1873-85 (2014)

5. S. Brethauer, C.E. Wyman, Biores. Tech. E 101, 4862-74 (2010)

6. S.R. Ajay Kumar Singh, Y. Kumar, H. Masih, J.K. Peter, J.C. Benjamin, P.K. Singh, Inter. J. Current Microbio. Appl. Sci. E 3, 84-96 (2014)

7. DC. Rakopoulos, C.D. Rakopoulos, E.C. Kakaras, E.G. Giakoumis, Ener. Conv. Manage. E 49(11), 3155-62 (2008)

8. J. Huang, Y. Wang, S. Li, A.P. Roskilly, H. Yu, H Li, App. Thermal Eng. E 29, 2484-90 (2009)

9. W-J. Lee, Y-C. Liu, F.K. Mwangi, W-H. Chen, S-L. Lin, Y. Fukushima, Ener. E 36, 5591-9 (2011)

10. A. Praptijanto, A. Muharam, A. Nur, Y. Putrasari, Ener. Proced. E 68, 345-54 (2015)

11. D. Hansdah, S. Murugan, L.M. Das, Alex. Eng. J. E 52, 267-76 (2013)

12. SH. Yalkowsky, Amer.hem. Soc. 464 (1999)

13. L. Lešnik, B. Vajda,Z Žunič, C. Škerget, B. Kegl, Appl. Ener. E 111, 558 - 70, (2013)

14. B. Shadidi, T. Yusaf, H.H.A. Alizadeh, B. Ghobadian, Appl. Ener. E 114, 874-9 (2014)

15. E. Alptekin, M. Canakci, A.N. Ozsezen, A. Turkcan, H. Sanli, Fuel E 157, 245-54 (2015)

16. MT. Cheng,HJ. Chen, LH. Young, HH. Yang, YI. Tsai, LC. Wang, J. Hazard. Mat. E 297, 234-40 (2015)

17. S. Lee, TY. Kim, Fuel E 162, 65-73 (2015)

18. H. Chen, S. Shi-Jin, W. Jian-Xin, Proceedings Combust. Ins. E 31, 2981-9 (2007)

19. L. Xingcai, H. Zhen, Z. Wugao, Li. Degang, Combust. Sci. Tech. E 176(8), 1309-29 (2004)

20. E. Alptekin, M. Canakci, A.N. Ozsezen, A. Turkcan, H. Sanli, Fuel E 157, 245-54 (2015)

21. Z. Chen, C. Yao, Q. Wang, G. Han, Z. Dou, H. Wei, Fuel E 170, 67-76 (2016)

22. U. Asad, R. Kumar, M. Zheng, J. Tjong, Appl. Ener. E157, 838-50 (2015)

23. R. Ballesteros, J. Guillen-Flores, J. Barba, Fuel E 157, 191-201 (2015)

24. VB. Pedrozo, I. May, NM. Dalla, A. Cairns, H. Zhao, Appl. Ener. E 165, 166-82 (2016) 